\title{
New species and new records of Dolichopodidae (Diptera) from Astrakhan Region of Russia
}

\section{Новые виды и новые указания Dolichopodidae (Diptera) из Астраханской области России}

\author{
I.Ya. Grichanov \\ И.Я. Гричанов
}

All-Russian Institute of Plant Protection, Podbelskiy roadway, 3, St. Petersburg-Pushkin 196608, Russia. E-mail: grichanov@mail.ru Всероссийский институт защиты растений, шоссе Подбельского, 3, Санкт-Петербург-Пушкин, 196608 Россия.

KEY WORDS: Diptera, Dolichopodidae, Palearctic Region, Russia, Astrakhan Region, new records, Campsicnemus, Vetimicrotes, new species, key.

КЛЮЧЕВЫЕ СЛОВА: Diptera, Dolichopodidae, Палеарктика, Россия, Астраханская область, новые указания, Campsicnemus, Vetimicrotes, новые виды, определитель.

ABSTRACT. The faunistic data of the results of collecting dolichopodids (12 species) in the Astrakhan Region in May, 2010 are presented. Most species are firstly recorded for the Region. Two new species are described and illustrated, Campsicnemus konstantini Grichanov sp.n. and Vetimicrotes baskunchakensis Grichanov sp.n.

РЕЗЮМЕ. Представлены результаты сборов долихоподид (12 видов) в Астраханской области в мае 2010 г. Большинство видов впервые отмечаются для области. Даны описания и иллюстрации Campsicnemus konstantini Grichanov sp.n. и Vetimicrotes baskunchakensis Grichanov sp.n., собранных на берегах озера Баскунчак.

\section{Introduction}

The Astrakhan Region lies in the North Caspian depression that is part of the continental or semi-arid desert biome. Regarding long-legged flies (Dolichopodidae), the region is largely undercollected. When studying recent Diptera catalogs, I have found that the dolichopodid fauna of the Astrakhan Region remained practically unstudied [Grichanov \& Negrobov, 1979; Negrobov, 1991; Grichanov, 2003-2010]. Only two species, Dolichopus zernyi Parent, 1927 and Hydrophorus praecox (Lehmann, 1822), were previously found on the territory of the Region. Dolichopus austriacus Parent was mentioned in the "Lower Volga" region.

Treating recent collections of the Zoological Museum of Moscow University (ZMU), I have found 10 known and two new peculiar species of Dolichopodidae. This paper confirms the old records and presents the new records in detail. Most species are widespread across the Palearctic Region, being often recorded in the neighboring territories. The easternmost finds of Rhaphium an- tennatum (Carlier, 1835) and Syntormon filiger Verrall, 1912 are worth noting. The collector of all specimens is Konstantin Tomkovich; his name and the name of the Region are omitted. Descriptions of two new species from environs of Baskunchak Lake are also given in this paper. Their paratypes are housed in the collection of the Zoological Institute, St. Petersburg (ZIN). The specimens were studied and illustrated with ZEISS Discovery V-12 stereomicroscope and AxioCam MRc5 camera. Morphological terminology follows Grichanov [2007] and Cumming \& Wood [2009]. The relative lengths of the podomeres should be regarded as representative ratios and not measurements. Body length is measured from the base of the antenna to the tip of epandrium. Wing length is measured from the base to the wing apex. Male genitalia were macerated in $10 \% \mathrm{KOH}$. Figures showing the male genitalia in lateral view are oriented as they appear on the intact specimen (rotated $180^{\circ}$ and lateroflexed to the right), with the morphologically ventral surface of the genitalia facing up, dorsal surface down, anterior end facing right and posterior end facing left. Distribution of known species follows those of Negrobov [1991] and Grichanov [2006, 2007].

\section{Descriptions and new records}

\section{Campsicnemus konstantini Grichanov, sp.n.} Figs $1-6$

TYPE MATERIAL. Holotype $\sigma^{7}$, Baskunchak salt-lake, $48.167^{\circ} \mathrm{N}, 46.830^{\circ} \mathrm{E}, 3-6 . \mathrm{V} .2010$, near lake, coll. K. Tomkovich [ZMU]. Paratypes: $10^{7}, 1$, , Baskunchak salt-lake, $48.193^{\circ} \mathrm{N}$, $46.813^{\circ} \mathrm{E}, 2-4 . \mathrm{V} .2010$, YPT, coll. K. Tomkovich [ZIN].

DESCRIPTION. Male. Length $(\mathrm{mm})$ : body 3.7, wing 3.7/1.0, antenna 0.9 , hypopygium 0.4 .

Head (Fig. 2). Frons shining blue-violet; ocellar and vertical bristles black, slightly more than half length of antennal stylus; occiput and vertex metallic, densely brown- 
ish-grey pollinose; face with black background, yellowishgrey pollinose, constricted at middle, in upper part about as wide as height of postpedicel, in middle half as latter, in lower part 1.5 times as wide as height of postpedicel; palpus small, oval, black, covered with white hairs and one black seta; proboscis black, extending below eye in lateral view; antennal segments elongate; scape and pedicel orange-yellow; postpedicel black, shortly haired, ovate, more than 2 times longer than high; stylus black, subapical, thickened at base, glabrous; length ratio of scape to pedicel to postpedicel to stylus ( $1^{\text {st }}$ and $2^{\text {nd }}$ segments $), 9 / 6 / 17 / 6 / 30$; lateral and lower postoculars long, yellow.
Thorax: Mesonotum and scutellum metallic, black, weakly brownish pollinose; pleura grey pollinose; thoracic setae black: 6-7 pairs of dorsocentrals in irregular rows (with penultimate dorsocentral distinctly shortened and offset medially); 2 notopleurals; 1 pair of strong scutellars with 2 lateral and 4 median marginal hairs; acrostichals very small, irregularly uniseriate; halter with yellow knob.

Legs: Fore coxa mainly yellow, black at base, with light hairs; mid and hind coxae black, grey pollinose; legs mainly dirty yellow; fore femur broadly black posteriorly; mid and hind femora black at base ventrally; tibiae blackish distally; tarsi mainly black except light base; process on fore tarsomere

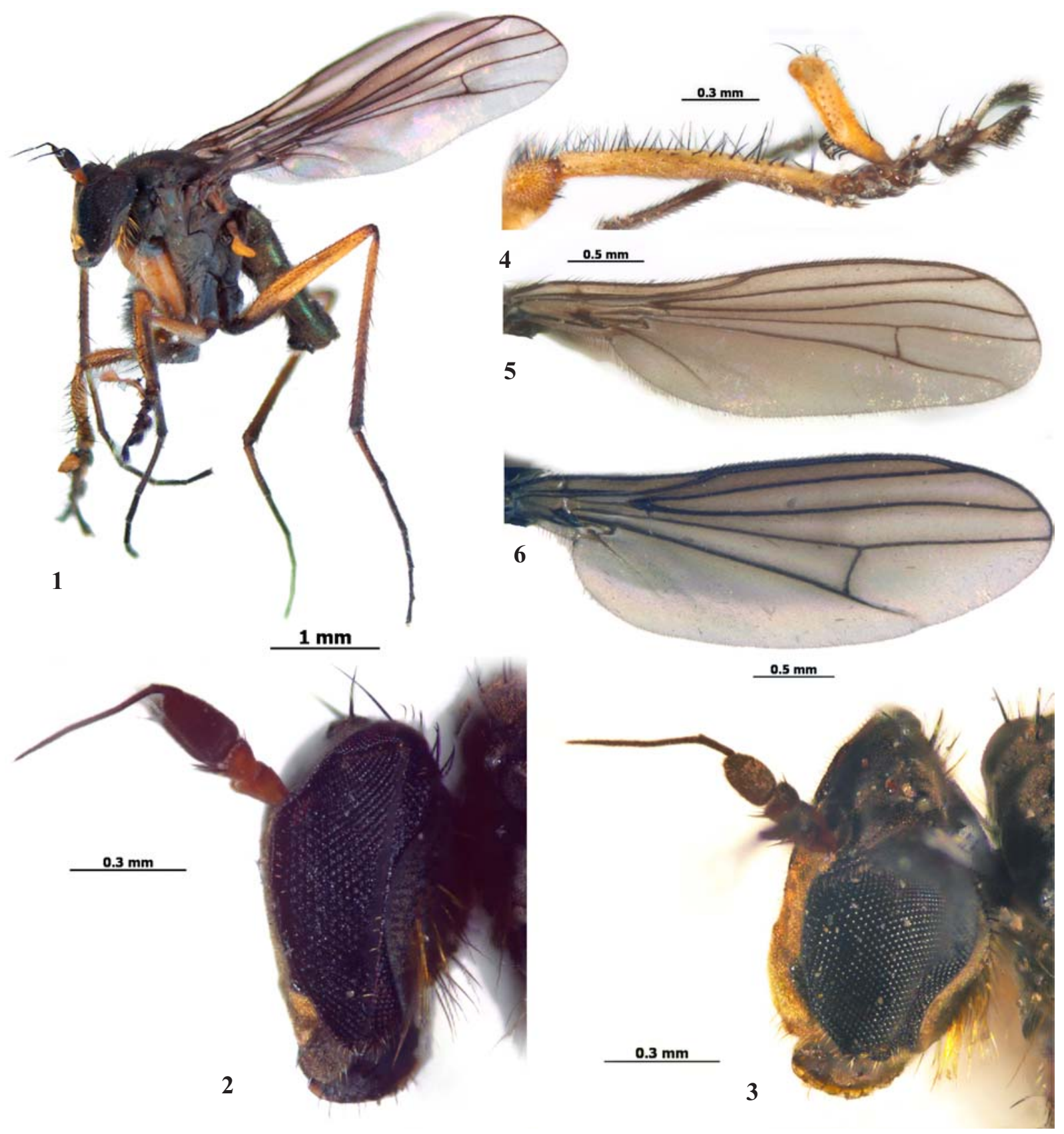

Figs 1-6. Campsicnemus konstantini Grichanov, sp.n.: 1 - habitus; $2-3$ - head; 4 - fore tibia and tarsus; $5-6$ - wing; 2, 4-5 - male; 3, 6 - female.

Pис. 1-6. Campsicnemus konstantini Grichanov, sp.n.: 1 - внешний вид; 2-3 - голова; 4- передняя голень и лапка; 5-6 - крыло; 2, 4-5 - самец; 3, 6 - самка. 
2 yellow; fore femur thickened on basal half, with long black posterior cilia, with some yellow posteroventral hairs at base; fore tibia evenly thickened along entire length, with black dorsal and posterior setae, longish on distal third; fore tarsomeres 1-4 short (Fig. 4); 2nd segment with short narrow apical process and with long thick flat process, glabrous on one side, covered with long hooked hairs on another side, with row of 7 hooked blunt setae on basal half; 3rd segment with short and flat lobe covered with black cilia; 4th segment with long narrow process covered with black cilia; 5 th segment elongate, slightly thickened at apex, with several apical setae, with 1 claw and 1 pulvilla; empodium reduced; mid and hind legs simple, with simple setae; mid and hind femora with single preapical bristle; mid tibia with $4-5$ dorsals and 2-3 ventrals; hind tibia with $8-9$ dorsals and 2 ventrals. Fore leg length ratio (from tibia to tarsomere 5): 83/15/10/10/8/15, mid leg: 130/48/ 26/24/20/17, hind leg: 158/40/35/25/21/17.

Wing (Fig. 5) pale smoky throughout; $\mathrm{R}_{4+5}$ and $\mathrm{M}_{1+2}$ almost straight and parallel behind level of $d m-c u$; ratio of cross-vein dm-cu to distal part of $\mathrm{CuA}_{1}, 15 / 55$; calypter yellowish, with black cilia.

Abdomen. Blackish-bronze, shining, weakly grey pollinose; with short black hairs dorsally on each tergite; tergites 1-2 with white hairs laterally; hypopygium black, with small black cercus covered with white hairs and with simple black surstylus, not dissected.

Female. Body length $3.4 \mathrm{~mm}$, wing 3.5/1.1 mm, antenna $0.8 \mathrm{~mm}$. Similar to male except lacking male secondary sexual characters. Eyes wider separated on face; face in middle about 2 times as wide as postpedicel height. Scape orange and pedicel mainly brown; postpedicel (Fig. 3) 1.5 times longer than high; length ratio of scape to pedicel to postpedicel to stylus ( $1^{\text {st }}$ and $2^{\text {nd }}$ segments $), 8 / 6 / 12 / 7 / 27$. Wing (Fig. 6) simple, smokier; ratio of cross-vein dm-cu to distal part of $\mathrm{CuA}_{1}, 20 / 38$.

DIAGNOSIS. The new species belongs to a group of species related to Campsicnemus magius (Loew). They are quite distinct in at least two basal segments of fore tarsus shortened and at least one segment of the same tarsus bearing very long process. The species of the group may be diagnosed by use of the following key [after Grichanov, 1998, 2009].

1. Fore tibia strongly dilated; tarsal segments 1,2 and 4 shortened, and $1^{\text {st }}-3^{\text {rd }}$ segments of fore tarsus bearing very long processes covered with long hairs; face golden-yellow; body length $3.0 \mathrm{~mm}$.............. magius (Loew, 1845)

- Fore tibia slightly dilated; face white or grey; tarsal segments variously ornamented

2. $1^{\text {st }} 4^{\text {th }}$ segments of fore tarsus shortened; process on $2^{\text {nd }}$ segment broad, bandlike; $5^{\text {th }}$ segment with only one claw; body length 3.4-3.7 mm .... konstantini Grichanov, sp.n.

- Two basal segments of fore tarsus shortened; process on $2^{\text {nd }}$ segment narrow .

3. $3^{\text {rd }}$ segment of fore tarsus elongate, longer than next two segments combined; $4^{\text {th }}$ segment without lobe; $5^{\text {th }}$ segment with only one claw; body length $1.85-2.5 \mathrm{~mm}$...... yangi Grichanov, 1998

$-3^{\text {rd }}$ segment of fore tarsus shorter than next two segments combined; $4^{\text {th }}$ segment with apical lobe; $5^{\text {th }}$ segment with 2 claws

3. Antenna entirely and legs mainly black; process on $2^{\text {nd }}$ segment of fore tarsus covered with long hairs at apex only; claws on same tarsus asymmetrical; body length $3.2-4.3 \mathrm{~mm}$........

bagachanovae Grichanov et Volfov, 2009

Antennal scape and pedicel yellow ventrally; legs mainly yellow-brownish; process on $2^{\text {nd }}$ segment of fore tarsus covered with long hairs along entire length; claws on same tarsus symmetrical; body length $2.25-2.5 \mathrm{~mm}$ compeditus Loew, 1857

ETYMOLOGY. The species is named for Konstantin Tomkovich (Moscow) who collected flies.

\section{Vetimicrotes baskunchakensis Grichanov, sp.n.} Figs 7-11

TYPE MATERIAL. Holotype $\sigma^{7}$, Baskunchak salt-lake, $48.193^{\circ} \mathrm{N}, 46.813^{\circ} \mathrm{E}, 2-4 . \mathrm{V} .2010$, YPT, coll. K. Tomkovich [ZMU]. Paratypes: $20^{7}, 1$, , same label [ZIN].

DESCRIPTION. Male. Length (mm): body 1.6, wing 1.6/1.0, antenna 0.6 , hypopygium 0.4 .

Head (Fig. 8). Vertex and frons dark metallic blue-green; face black, densely grey pollinose, under antenna as wide as postpedicel height; clypeus bulging; palpi brown, with 3 black apical seta; proboscis brown, projecting anteriorly, keel-like; single row of strong postoculars; lateral and lower ones light; antenna black; pedicel with large inner projection, with apical setae on dorsal and outer sides; postpedicel large, pointed, 2 times as long as basal height, densely pubescent; stylus subapical, short, bare; length ratio of scape to pedicel to postpedicel to stylus (1st and 2nd segments), 6/9/15/2/6.

Thorax: Metallic, dark blue-green, weakly pollinose; posterior third of mesonotum flattened; thoracic setae black; 56 pairs of acrostichals of equal length in 2 irregular rows; 6 pairs of strong dorsocentrals, decreasing in size anteriorly; posterior two pairs offset laterad; 2 pairs of scutellars, laterals microscopic, at base of medians; 2 unequal proepisternals just above fore coxa.

Legs: mainly dirty yellow, fore coxa blackish anteriorly, mid and hind coxae black, all femora black except basal and distal apices (holotype) or blackish in middle half (paratypes); hind tibia gradually darkened towards distal apex; anterior four tarsi brown from tip of basitarsus, hind tarsus blackish; fore and mid coxae with black anterior setae; hind coxa with 1 strong black lateral bristle; major leg setae black; mid and hind femora each with strong preapical bristle; fore tibia with anterodorsal seta; mid tibia with strong anterodorsal and posterodorsal at $1 / 5$, weaker anterodorsal and posterodorsal at $2 / 3$, an apical ring of 4 bristles; hind tibia with 2 anterodorsal and 4 posterodorsal setae. Fore leg length ratio (from tibia to tarsomere 5): 35/13/7/5/5/6, mid leg: 46/19/10/ 7/6/6, hind leg: 50/12/12/8/6/7.

Wing (Fig. 9) simple, hyaline: $\mathrm{R}_{2+3}$ and $\mathrm{R}_{4+5}$ straight, diverging to wing apex; $\mathrm{M}_{1+2}$ with inconspicuous curvature in distal part; $\mathrm{M}_{1+2}$ and $\mathrm{R}_{4+5}$ almost parallel. $\mathrm{M}_{1+2}$ joining costa right before wing apex. Ratio of part of costa between $\mathrm{R}_{2+3}$ and $\mathrm{R}_{4+5}$ to this between $\mathrm{R}_{4+5}$ and $\mathrm{M}_{1+2}$ to dm-cu to distal part of $\mathrm{CuA}_{1}, 14 / 8 / 6 / 38$. Crossvein $d m$-cu straight, forming right angle with $\mathrm{CuA}_{1}$ and with $\mathrm{M}_{1+2}$ longitudinal veins. Anal vein fold-like; anal lobe present; alula absent. Lower calypter yellow, with pale setae. Halter yellow.

Abdomen: metallic, dark blue-green, covered with black setae (including terga 6 to 8 ); $4^{\text {th }}$ to $7^{\text {th }}$ sterna weakly sclerotised, somewhat recessed; segment 7 black, about as large as 6 th one, with well developed symmetrical tergum and sternum; segment 8 black, with setae. Hypopygium (Fig. 10) black; epandrium with left lateral foramen; hypandrium fused with epandrium at base, with 2 basal arms, asymmetrical; hypandrium (Fig. 11) broad at base, narrowed at middle, broadly rounded at apex, with triangular projection right laterally (ventral view); phallus mainly concealed, with apical part as narrow sclerotised hook projecting above hypandrium (lateral view); 1 strong and 2 short epandrial setae at base of hypandrium; surstylus yellow, simple, broad, flat, half as long as cercus, with a few short subapical setae; cercus 
yellow, long and slender, inconspicuously longer than epandrium, regularly covered with short setae, with one stronger apical seta; cerci fused at base, with small median projection.

Female. Body length $1.8 \mathrm{~mm}$, wing length $1.9 \mathrm{~mm}$. Similar to male except lacking male secondary sexual characters. Eyes wider separated on face; pedicel with smaller inner projection; postpedicel as long as high; arista-like stylus as long as 3 antennal segments combined; all femora brown in middle half; each hemitergite with 5 short thick setae; cercus long and thin, with long yellow setae.

DIAGNOSIS. The new species may be distinguished from other known Vetimicrotes species by use of the following key [see Beschovski, 1972 and Negrobov, 1976].

1. Femora entirely yellow; fore coxa with light hairs; male antenna with stylus about half as long as postpedicel; male surstylus reaching 3/4 the length of cercus; body length 1.4-1.5 mm (female unknown) nartshukae (Negrobov, 1976)

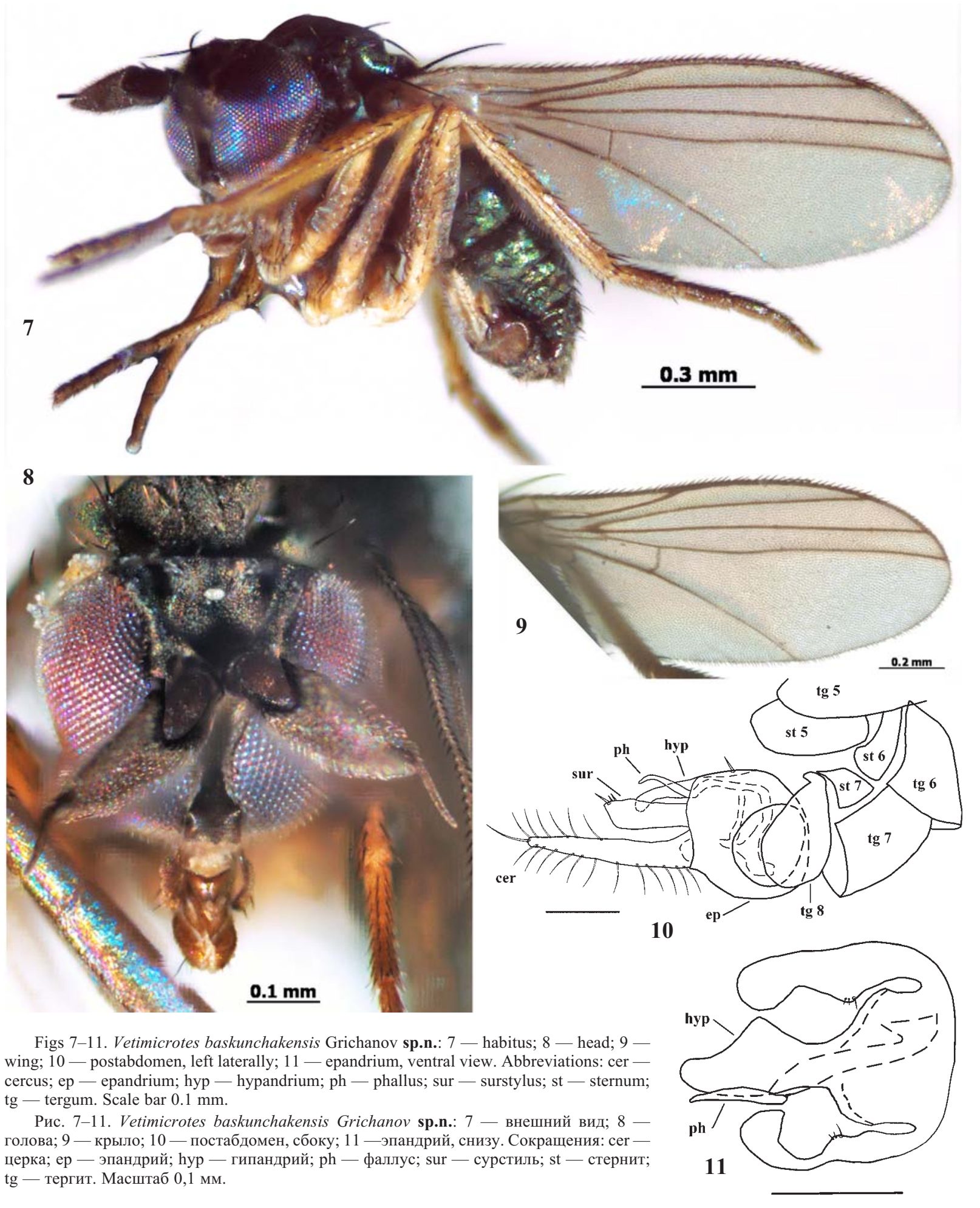


- Femora black or brown in at least middle half; fore coxa with black setae (females indistinguishable) ..................... 2

2. Male antenna with stylus about half as long as postpedicel; male surstylus half as long as cercus; body length 1.6-1.8 mm ....................... baskunchakensis Grichanov, sp.n.

- Male antenna with stylus slightly longer than postpedicel; male surstylus reaching 3/4 the length of cercus; body length 1-2 mm ............. mediterraneus (Becker, 1918) ETYMOLOGY. The species is named for the Baskunchak Lake, where it was collected.

\section{Campsicnemus magius (Loew, 1845)}

MATERIAL EXAMINED: 207, Baskunchak salt-lake, $48.193^{\circ} \mathrm{N}, 46.813^{\circ} \mathrm{E}, 2-4 . \mathrm{V} .2010$, fresh pond silt.

TYPE LOCALITY: Italy: Sicily.

DISTRIBUTION: Algeria, Austria, Azerbaijan, Belgium, Bulgaria, Czech, France, Germany, Hungary, Italy, Israel, Netherlands, ?Slovenia, Spain, Romania, Russia (Astrakhan, Kabardino-Balkaria, Krasnodar, Rostov, Sverdlovsk), Tajikistan, Turkmenistan, UK, Ukraine (Odessa), Uzbekistan, "Yugoslavia"; Afrotropical: St. Helena (?introduced).

\section{Chrysotus suavis Loew, 1857}

MATERIAL EXAMINED: 4ণ', Ikryanoe district, Zyuzino, $45.751^{\circ} \mathrm{N}, 47.678^{\circ} \mathrm{E}, 8-9 . V .2010$, water, pastures.

TYPE LOCALITY: Germany: "Coin"; Austria: "Neusiedler See in Ungarn".

DISTRIBUTION: Armenia; Azerbaijan; Bulgaria; Egypt; Georgia; Greece (North Aegean); Iraq; Iran, Israel; Romania; S Russia (Adygea, Alania, Astrakhan, Kabardino-Balkaria, Krasnodar, Rostov), Turkey; Ukraine (Cherkasy, Kherson, Odessa), Transpalearctic species.

\section{Dolichopus austriacus Parent, 1927}

MATERIAL EXAMINED: $40^{7}$, Ikryanoe, river bank, $46.112^{\circ} \mathrm{N}$, 47.767 E, 10.V.2010, Ulmus-Salix.

TYPE LOCALITY: Austria: Gmunden.

DISTRIBUTION: Austria, Estonia, Germany, Romania, Russia (Astrakhan), Sweden, Uzbekistan.

\section{Dolichopus zernyi Parent, 1927}

MATERIAL EXAMINED: $4 \sigma^{\top}$, Ikryanoe, river bank, $46.112^{\circ} \mathrm{N}$, 47.767 E, 10.V.2010, Ulmus-Salix.

TYPE LOCALITY: Russia: "Sarepta" [=Krasnoarmeysk, near Volgograd].

DISTRIBUTION: China (Xinjiang), Kazakhstan, Russia (Astrakhan, Volgograd, Voronezh).

Hydrophorus praecox (Lehmann, 1822)

MATERIAL EXAMINED: $3 \sigma^{\top}, 3$, Baskunchak salt-lake, $48.193^{\circ} \mathrm{N}, 46.813^{\circ} \mathrm{E}, 2-4$.V.2010, fresh pond silt.

TYPE LOCALITY: Germany: Hamburg.

DISTRIBUTION: Abkhazia, Azerbaijan, Bulgaria, Cyprus, Egypt, Georgia, Greece (Crete, North Aegean), Iraq, Iran, Israel, Romania, S Russia (Astrakhan, Kabardino-Balkaria, Krasnodar, Stavropol'), Turkey, Ukraine (Crimea, Kherson, Odessa), Palaearctic, Afrotropical, Oriental Regions, Australia, Oceania, New Zealand.

\section{Rhaphium antennatum (Carlier, 1835)}

MATERIAL EXAMINED: $10^{7}$, Baskunchak salt-lake, $48.193^{\circ} \mathrm{N}, 46.813^{\circ} \mathrm{E}, 2-4 . V .2010$, YPT.

TYPE LOCALITY: Belgium: "Kimkempois pres de liege",

DISTRIBUTION: Austria, Belgium, Czech, Estonia, Finland, Germany, Hungary, Moldova, Netherlands, Norway, Poland, Romania, Russia (Arkhangelsk, Astrakhan, Karelia, Krasnodar, Leningrad, Lipetsk, Moscow, Murmansk, Voronezh), Slovakia, UK, Ukraine (Odessa).

\section{Rhaphium micans (Meigen, 1824)}

MATERIAL EXAMINED: 20', Ikryanoe district, Zyuzino, $45.751^{\circ} \mathrm{N}, 47.678^{\circ} \mathrm{E}, 8-9 . \mathrm{V} .2010$, water, pastures; $10^{7}$, Ikryanoe, river bank, $46.112^{\circ} \mathrm{N}, 47.767^{\circ} \mathrm{E}, 10 . \mathrm{V} .2010$, Ulmus-Salix.

TYPE LOCALITY: Germany: Hamburg.

DISTRIBUTION: Abkhazia, Austria, Azerbaijan, Belarus, Belgium, Bulgaria, China, Czech, Finland, France, Germany, Hungary, Italy, Latvia, Netherlands, Norway, Poland, Romania, Russia (Astrakhan, Kabardino-Balkaria, Karelia, Karachai-Cherkessia, Krasnodar, Leningrad, Pskov, Rostov, Ryazan, Voronezh, Krasnoyarsk, Primorskii Terr.), Slovakia, Spain, Sweden, Switzerland, Tajikistan, Turkey, UK, "Yugoslavia".

\section{Syntormon filiger Verrall, 1912}

MATERIAL EXAMINED: $10^{\Upsilon}, 2$, Ikryanoe district, Zyuzino, $45.751^{\circ} \mathrm{N}, 47.678^{\circ} \mathrm{E}, 8-9 . \mathrm{V} .2010$, water, pastures.

TYPE LOCALITY: England: Walton-on Naze, Woolbridge, Aldeburgh.

DISTRIBUTION: Austria, Belgium, Bulgaria, Czech, Denmark, Finland, France, Germany, Greece (North Aegean), Russia (Astrakhan, Rostov), Hungary, Netherlands, Poland, Sweden, UK, Ukraine (Crimea).

\section{Syntormon pumilus (Meigen, 1824)}

MATERIAL EXAMINED: $1^{\circ}$, Baskunchak salt-lake, $48.193^{\circ} \mathrm{N}$, 46.813 ${ }^{\circ} \mathrm{E}, 2-4$.V.2010, YPT.

TYPE LOCALITY: not given.

DISTRIBUTION: Afghanistan, Armenia, Austria, Belarus, Belgium, Bulgaria, Czech, Denmark, ?Egypt; Estonia, Finland, France, Germany, Great Britain, ?Greece, Hungary, Ireland, ?Israel, Italy, Latvia, Morocco, Norway, Poland, Romania, Russia (Astrakhan, Kabardino-Balkaria, Karelia, Krasnodar, Leningrad, Murmansk, Pskov, Stavropol'), Slovakia, ?Slovenia, Sweden, Spain (Canary Is.), Tunisia, Ukraine (Kherson, Odessa), "Yugoslavia"; Middle Asia [Some records may belong to Syntormon denticulatus (Zetterstedt, 1843) and should be confirmed].

Thinophilus flavipalpis (Zetterstedt, 1843)

MATERIAL EXAMINED: $10^{7}$, Baskunchak salt-lake, $48.167^{\circ} \mathrm{N}, 46.830^{\circ} \mathrm{E}, 3-6 . \mathrm{V} .2010$, near lake.

TYPE LOCALITY: Sweden: Gottlandia, Bursviken.

DISTRIBUTION: Austria, Azerbaijan, Belgium, Bulgaria, Czech, Denmark, Egypt, Estonia, Finland, France, Germany, Greece (Crete, North Aegean), Hungary, Israel, Italy, Kazakhstan, Kyrgyzstan, Moldova, Mongolia, Netherlands, Poland, Portugal, Romania, S Russia (Krasnodar, Rostov), Spain, Sweden, Syria, UK, Ukraine (Crimea, Kherson, Odessa), "Yugoslavia", N China; Oriental China.

ACKNOWLEDGMENTS. The author expresses sincere gratitude to Drs. Nikita Vikhrev and Andrei Ozerov (Moscow) for their kindness in furnishing an opportunity to study the collections of their museum.

\section{References}

Beschovski V. 1972. Sur le Microtes mediterraneus Becker, 1919 (Diptera, Dolichopodidae) de litoral bulgare de la Mer Noire. // Entomologische Berichten. Vol.32. No.7. P.141-144.

Cumming J.M. \& Wood D.M. 2009. Adult morphology and terminology [Chapter] 2 // B.V. Brown, A. Borkent, J.M. Cumming, D.M. Wood, N.E. Woodley \& M.A. Zumbado (eds.). Manual of Central American Diptera. Vol.1. Ottawa, Ontario, Canada: NRC Research Press. P.9-50. 
Grichanov I.Ya. 1998. Two new species of Campsicnemus Haliday (Diptera: Dolichopodidae) from Tropical Africa // International Journal of Dipterological Research. Vol.9. No.2. P.109-113.

Grichanov I.Ya. 2003-2010. A check list of species of the family Dolichopodidae (Diptera) of the World arranged by alphabetic list of generic names. http://grichanov.fortunecity.com.

Grichanov I.Ya. 2006. A checklist and keys to North European genera and species of Dolichopodidae (Diptera) // Plant Protection News Supplement. All-Russian Institute of Plant Protection, St. Petersburg. P.1-120.

Grichanov I.Ya. 2007. A checklist and keys to Dolichopodidae (Diptera) of the Caucasus and East Mediterranean // Plant Protection News Supplement. All-Russian Institute of Plant Protection, St. Petersburg. P.1-160.

Grichanov I.Ya. 2009. A new species of Campsicnemus Haliday from Azerbaijan with a key to the Palearctic species of the genus (Diptera: Dolichopodidae) // Far Eastern Entomologist. No.198. P.1-16.

Grichanov IYY \& Negrobov O P 1979. [Catalogue for the family Dolichopodidae (Diptera) in the USSR]. Voronezh: Voronezh Univ. 128 p. Dep. in VINITI, Moscow 04.02.80, N417-80 dep. [in Russian].

Negrobov O.P. 1976.[ New and little-known species of Dolichopodidae (Diptera) of the fauna of USSR and adjacent territories] Nauchnye doklady vysshei shkoly. Biologicheskie nauki. No.8. P.45-50 [in Russian].

Negrobov O.P. 1991. Dolichopodidae // A. Soos, L. Papp, P. Oosterbroeck (eds.). Catalogue of Palaearctic Diptera. Vol.7. Dolichopodidae-Platypezidae. Budapest: Akademiai Kiado. 291 p. 